\title{
Anatomic and molecular characterization of the endocrine pancreas of a teleostean fish: Atlantic wolffish (Anarhichas lupus)
}

\author{
Jessica S Fortin ${ }^{1 *}$, Ariane Santamaria-Bouvier ${ }^{2}$, Stéphane Lair², André D Dallaire ${ }^{1}$ \\ and Marie-Odile Benoit-Biancamano ${ }^{1 *}$
}

\begin{abstract}
Background: The biologic attributes of the endocrine pancreas and the comparative endocrinology of islet amyloid polypeptide (IAPP) of fish are not well described in the literature. This study describes the endocrine pancreas of one teleostean fish. Ten captive Atlantic wolffish (Anarhichas lupus) from the Montreal Biodome were submitted for necropsy and their pancreata were collected.

Results: Grossly, all the fish pancreata examined contained 1-3 nodules of variable diameter (1-8 mm). Microscopically, the nodules were uniform, highly cellular, and composed of polygonal to elongated cells. Immunofluorescence for pancreatic hormones was performed. The nodules were immunoreactive for insulin most prominent centrally, but with IAPP and glucagon only in the periphery of the nodules. Exocrine pancreas was positive for chromogranin A. Not previously recognized in fish, IAPP immunoreactivity occurred in a, glucagon-containing, cells and did not co-localize with insulin in $\beta$ cells. The islet tissues were devoid of amyloid deposits. IAPP DNA sequencing was performed to compare the sequence among teleost fish and the potency to form amyloid fibrils. In silico analysis of the amino acid sequences 19-34 revealed that it was not amyloidogenic.
\end{abstract}

Conclusions: Amyloidosis of pancreatic islets would not be expected as a spontaneous disease in the Atlantic wolffish. Our study underlines that this teleost fish is a potential candidate for pancreatic xenograft research.

Keywords: Beta cells; Endocrine pancreas; Glucagon; Insulin; Islet amyloid polypeptide (IAPP); Teleost fish

\section{Background}

The pancreas is an endodermal organ found in all vertebrates with two different functional components that are essential for the homeostatic regulation of glucose and food digestion. The exocrine pancreas is composed of acinar and duct cells involved in the production and transport of digestive enzymes into the gut, whereas the endocrine compartment regulates the production and secretion of peptide hormones into the bloodstream. In higher vertebrates, there are five endocrine cell types that cluster as the islets of Langerhans. The hormonal expression is specific to each cell type: glucagon ( $\alpha$ cells), insulin ( $\beta$ cells), somatostatin

\footnotetext{
*Correspondence: Jessica.fortin.2@umontreal.ca; marie-odile.benoit-biancamano@umontreal.ca

'Département de pathologie et de microbiologie, Faculté de médecine vétérinaire, Université de Montréal, 3200 Sicotte, Saint-Hyacinthe, QC J2S 2M2, Canada

Full list of author information is available at the end of the article
}

( $\delta$ cells), ghrelin ( $\varepsilon$ cells), and pancreatic polypeptide (PP cells) (Ali 1985).

The pancreatic tissues of several species of teleost fish have been described and a complete separation of exocrine and endocrine parenchyma occurs (Ali 1985; Nguyen et al. 1995). The islet tissues of some teleost fish are concentrated in two principal islets (Brockmann bodies): one is found near the spleen and the other is located inside the wall of the duodenum, at the pyloric junction (Cutfield et al. 1986). These islets contain insulin, glucagon, and somatostatin, but only the pyloric Brockmann bodies secrete pancreatic polypeptide (Falkmer and Olsson 1962). The isolation and characterization of glucagon, insulin, somatostatin, and pancreatic polypeptide from islet tissues of several teleost fish were previously described (Cutfield et al. 1986; Conlon et al. 1987a; Conlon et al. 1987b; Conlon et al. 1986; Cutfield et al. 1987; Cutfield and Cutfield 1993). The amino acid 
sequence and primary structure of teleost islet hormones slightly differs from their higher vertebrate counterparts (Nguyen et al. 1995; Cutfield et al. 1986; Falkmer and Olsson 1962; Conlon et al. 1987a; Conlon et al. 1987b; Conlon et al. 1986; Cutfield et al. 1987; Cutfield and Cutfield 1993). Islet amyloid polypeptide (IAPP) is a hormone of 37 amino acids that is co-secreted with insulin by the $\beta$ cells of mammals (Westermark et al. 2011). This protein, namely amylin, can generate amyloid fibril deposits found naturally in the human and cats, but pancreatic islet amyloid fibrils, in contrast to serum amyloid fibrils, are not found in rat and mouse (Westermark et al. 2011). Amyloid fibril formation contributes to the pathogenesis of diabetes mellitus in humans and cats (Westermark et al. 2011). IAPP has been described in pancreatic islet parenchyma of daddy sculpin (Myoxocephalus scorpius) (Westermark et al. 2002); however, the comparative endocrinology of IAPP and the propensity to form amyloid deposits remain to be elucidated in lower vertebrates.

Since the last decade, teleost species have become important as model systems in different areas of hormonal, metabolic, and immunologic research (Intine et al. 2013; McGonnell and Fowkes 2006). One advantage of using teleost fish in studies of diabetes mellitus is that the pancreatic endocrine cells are separated from the pancreatic exocrine tissue and can be easily isolated and harvested. Therefore, the Brockmann body of teleost fish, particularly the tilapia (Oreochromis nilotica), has been investigated as a potential xenograft tissue for patients with type 1 diabetes (Nguyen et al. 1995). The transplantation of tilapia Brockmann bodies into a diabetic nude mice model has been shown to promote long-term normoglycemia responsive to intraperitoneal glucose administration (Wright et al. 2004; Yang et al. 1997). However, islet amyloid formation is a major hindrance to pancreatic transplant resulting in non-immunologic transplanted islet graft loss in a primate transplant model (Liu et al. 2012). It is important for the xenograft success of microencapsulated pancreatic endocrine cells to identify which species of teleost fish could be used without the amyloidosis risk. To promote comparative understandings in endocrine pathophysiology, the pancreatic hormonal expression and localization in lower vertebrates should be further clarified.

In this study, we describe the principal islets (Brockmann bodies) of a different teleost species, the Atlantic wolffish (Anarhichas lupus), using immunohistochemical and immunofluorescence techniques in an attempt to better understand the physiological regulation of glucose and the potential usefulness of this teleost fish in endocrinological studies. These endocrine pancreas bodies of fish have occasionally been mistaken for endocrine tumors by pathologists; thus, we also clarify endocrine pancreas structure and function for comparative pathologists. The comparative pancreatic endocrinology of IAPP is poorly described in fish; we therefore focused our study on the isolation of the IAPP gene from the Atlantic wolfish pancreatic tissues. The amino acid sequences of the IAPP were determined, and the in silico analysis was performed to compare the amyloidogenicity of Anarhichas IAPP to other vertebrate species.

\section{Methods}

\section{Atlantic wolffish (A. lupus)}

All fish were obtained from the Montreal Biodome that maintained aquariums. Atlantic wolffish were approximately 9 to 10 years old and submitted dead on ice at the necropsy services for diagnostic purpose. Necropsy was done approximately $1 \mathrm{~h}$ after death, and all were well preserved. Pancreata were collected and fixed in $10 \%$ neutral buffered formalin, trimmed, and embedded in paraffin.

\section{Routine staining, special stains, and immunohistochemistry}

The paraffin sections $(4 \mu \mathrm{m})$ were stained with hematoxylineosin-phloxine-saffron (HEPS) for the histologic analysis of all organs. Pancreatic sections were stained with Congo red to reveal amyloid deposits and Grimelius to identify neuroendocrine cells.

For immunohistochemistry procedure, pancreatic sections were deparaffinized and washed with $\mathrm{PBS}(\mathrm{pH}$ 7.4) for $20 \mathrm{~min}$. They were next permeabilized and blocked with $0.1 \%$ saponin and 3\% $(w / v)$ BSA in PBS. The tissue sections were further incubated during $1 \mathrm{~h}$ at $37^{\circ} \mathrm{C}$. Immunofluorescence was performed with monoclonal antibodies against insulin, IAPP, glucagon, and somatostatin (Santa Cruz Biotechnology, Dallas, TX, USA). All were rabbit monoclonal antibody except for IAPP, which was a mouse monoclonal antibody. Rabbit anti-chromogranin A, anti-pancreatic polypeptide, and anti-synaptophysin antibodies were purchased from Thermo Fisher Scientific (Waltham, MA, USA). Each antibody was applied overnight at $4^{\circ} \mathrm{C}$ at a $1 / 50$ dilution with a solution containing $0.1 \%$ saponin and 3\% $(w / v)$ BSA. The pancreatic sections were washed three times with PBS containing $0.05 \%$ Tween $20^{\mathrm{mm}}$ and then incubated $1 \mathrm{~h}$ at $37^{\circ} \mathrm{C}$ in the blocking buffer containing a secondary antibody. Antirabbit Alexa 488 and anti-mouse Alexa 594 were used as secondary antibodies at 1/1,000 dilutions (Santa Cruz Biotechnology, Dallas, TX, USA). Negative controls were performed using the serum corresponding to the type of the secondary antibody used (mouse or rabbit). After three washes, slides were mounted with anti-fade reagent (DakoCytomation, Carpinteria, CA, USA). The cellular distribution of each pancreatic hormone was assessed using a DMI 4000B reverse fluorescence microscope. Images were captured as 8-bit tagged image format files with a DFC 490 digital camera, and the images were analyzed using the Leica Application Suite Software, version 2.4.0 
(Leica Microsystems Inc., Richmond Hill, ON, Canada). Data are representative of all specimens collected.

\section{Isolation and sequencing of Anarhichas IAPP DNA}

To sequence the IAPP gene, DNA was isolated from paraffin-embedded pancreatic tissues using a DNeasy tissue kit (Qiagen, Toronto, ON, Canada). Fast-cycling PCR DNA synthesis was performed with a Techne TC-512 thermocycler with the following PCR protocol: $5 \mathrm{~min}$ at $96^{\circ} \mathrm{C}$; $45 \mathrm{cy}-$ cles of $5 \mathrm{~s}$ at $96^{\circ} \mathrm{C}, 5 \mathrm{~s}$ at $53^{\circ} \mathrm{C}$, and $5 \mathrm{~s}$ at $68^{\circ} \mathrm{C}$; and a final extension of $1 \mathrm{~min}$ at $72^{\circ} \mathrm{C}$. Each PCR reaction consisted of $500 \mathrm{nM}$ of IAPP primers (forward and reverse), $300 \mathrm{ng}$ of DNA, and $10 \mu \mathrm{L}$ of fast-cycling Taq DNA polymerase master mix (Qiagen, Toronto, ON, Canada). Degenerate IAPP forward (5'-AAGTGCAACACAGCCACCTG-3') and reverse (5'-CGTTTKCCGTAGGTRTTDCGA-3') primers were used and covered the seven first and three last amino acids of the IAPP peptide (Westermark et al. 2002). PCR products were visualized in a $2 \%(\mathrm{~m} / \mathrm{v})$ agarose gel with ethidium bromide, and bands of the expected size were extracted (Zymoclean $^{\mathrm{Tw}}$ Gel DNA Recovery Kit, Cedarlane Labs, Burlington, NC, USA). A second PCR was performed using the same primers with the following PCR protocol: $5 \mathrm{~min}$ at $96^{\circ} \mathrm{C} ; 45$ cycles of $5 \mathrm{~s}$ at $96^{\circ} \mathrm{C}, 5 \mathrm{~s}$ at $54^{\circ} \mathrm{C}$, and $5 \mathrm{~s}$ at $68^{\circ} \mathrm{C}$; and a final extension of $1 \mathrm{~min}$ at $72^{\circ} \mathrm{C}$. Sequencing was performed using the Mcgill gene sequencing platform. The amino acid sequence of Anarhichas IAPP was deducted based on DNA sequence (http://didac.free.fr/ seq/dna2pro.htm).

\section{In silico analysis of fibril formation}

The tendency for $\beta$-sheet aggregation of each amino acid sequence was calculated based on the Agg parameter, obtained using in silico analysis with the TANGO program (http://tango.crg.es), which predicts protein aggregation. A higher Agg score is indicative of a peptide that can form potentially toxic aggregates. The amino acid sequence in the 19-34 segment of Atlantic salmon (Salmo salar), daddy sculpin (M. scorpius), and zebrafish (Danio rerio) IAPP previously published were selected to compare the
Agg parameter (Westermark et al. 2002). Human and feline IAPP amino acid sequences were used as positive controls, and rodent IAPP was representative of a negative control. Control sequences were obtained from GenBank (www.ncbi.nlm.nih.gov/Genbank), with the following accession numbers: Homo sapiens [GenBank: M26650.1], Felis catus [GenBank: NM001043338.1], Rattus norvegicus [GenBank: NM012586.2].

\section{Results}

\section{Macroscopic and microscopic examination}

At necropsy, the pancreas was surrounded by adipose tissue. Figure 1A shows the gross appearance of the pancreas from an Atlantic wolffish, the arrows indicate the pancreatic tissue surrounded by adipose tissue. All the fish pancreata examined contained one to three nodules (Figure 1B) of variable diameter $(1-8 \mathrm{~mm})$ within the pancreas. Nodules were further isolated for histopathological examination (Figure 2A) revealing pancreatic islet cells in nodules sometimes surrounded by exocrine pancreatic tissue, though the specific subtopographical location of each nodule was not recorded at necropsy. The nodules consisted of uniform polygonal to elliptical cells and were surrounded by a delicate connective tissue capsule. Smaller nodules were completely embedded in exocrine tissue (Figure 2B) whereas larger nodules were not consistently completely encased in exocrine pancreas. Discrete nodules consisting of exocrine pancreatic tissue were also observed (Figure 2C).

\section{Immunohistochemistry and special stains}

Using immunofluorescence with an antibody against insulin (Figure 3A), a large number of $\beta$ cells was observed. The elliptical $\beta$ cells were found in most parts of the nodular islet not just on the periphery of the nodule. Other islet cells stained immunocytochemically positive for glucagon (Figure 3B). The $\alpha$ cells (glucagon containing) were confined to the periphery of the nodular islet encircling the $\beta$ cells located in the center. Infrequently, glucagon-containing cells were noticed in the center of the nodule. Interestingly, IAPP was found at the periphery
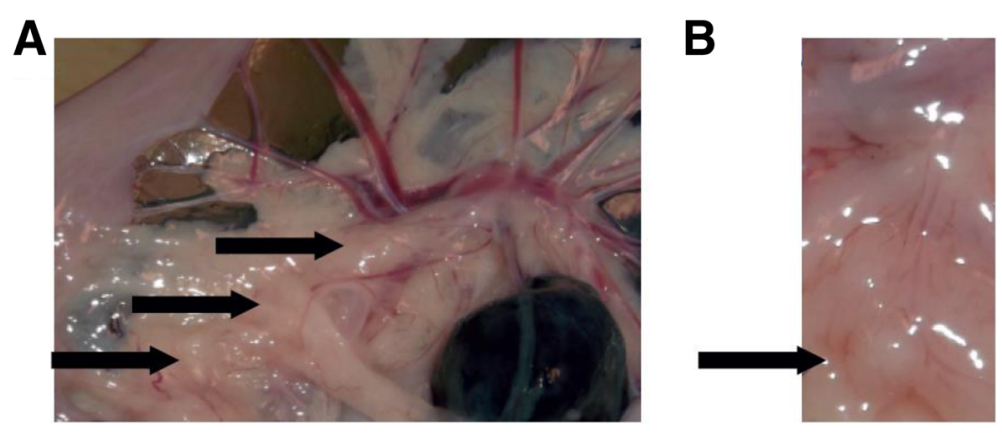

Figure 1 Brockmann bodies isolated from an Atlantic wolffish. (A) Pancreatic tissues are scattered in the mesentery (black arrows). (B) The Brockmann body is indicated with an arrow. 

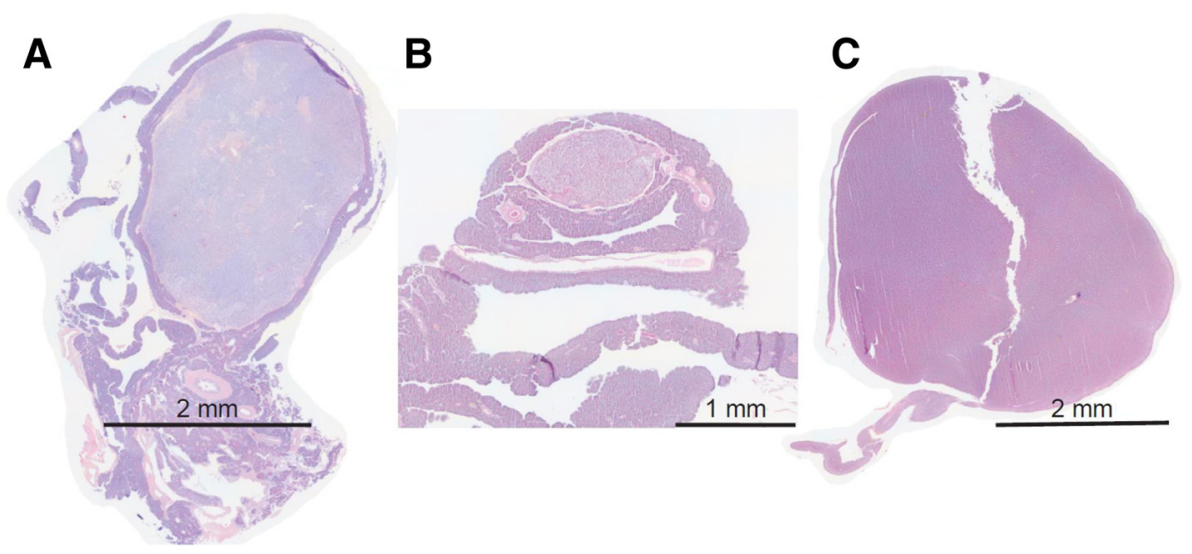

Figure 2 Microscopic features of excised nodules from the pancreas (HEPS stain). (A) Principal islet. (B) Smaller islets embedded in exocrine tissues. (C) Exocrine nodule from an Atlantic wolffish.

of the islet tissue and did not co-localize with insulin (Figure 3A). Instead, IAPP co-localized in $\alpha$ cells containing glucagon (Figure 3B).

Several islet nodules were surrounded by exocrine tissue. The exocrine cells were immunoreactive with chromogranin A (Figure 3C). One nodule of exocrine tissue occurred and immunoreacted positively with the antibody targeting chromogranin A (Figure 3D). None of the antibodies against somatostatin, pancreatic polypeptide, or synaptophysin reacted with islet tissue. When standard controls were carried out, negative immunofluorescence occurred consistently in all experiments. Noteworthy, Congo red and Grimelius staining of the islet cells from Atlantic wolffish were negative (Figure 4) for amyloid or neuroendocrine cells respectfully.
DNA sequence of Anarhichas IAPP and in silico analysis

We isolated DNA of teleost fish to amplify and sequence the IAPP gene and compared it to other species. PCR of DNA from the Atlantic wolffish resulted in a band of 120 base pairs. The amino acid sequence translated after the sequencing reaction is shown in Table 1. Anarhichas IAPP DNA is very different among the mammals and other teleost fish. The amino acid at position 19, 20, and 33 are highly conserved among the teleost fish. The IAPP amino acid sequences from all teleost fish are devoid of the GAILS region (amino acid positions 24-28) found in mammal IAPP amino acid sequences. GAILS represents an amino acid sequence at positions 24-28 in IAPP. The amino acid sequence GAILS contributes in part to the fibrillization process of IAPP. Two proline residues were
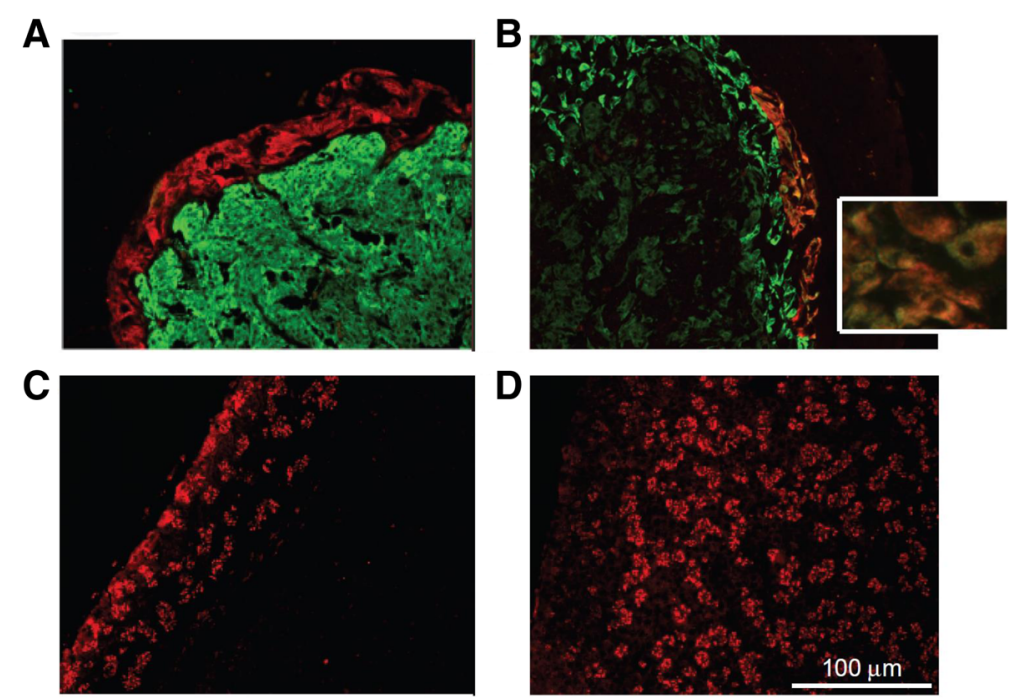

Figure 3 Histological sections of the pancreatic nodules with immunoreactivity to the pancreatic hormones of Atlantic wolffish. (A) Insulin (green) and IAPP (red) in the endocrine tissue. (B) Glucagon (green) and IAPP (red) in the endocrine tissue. (C) Chromogranin A surrounding the endocrine nodules. (D) The exocrine nodule with immunoreactivity to chromogranin A was isolated from an Atlantic wolffish. 


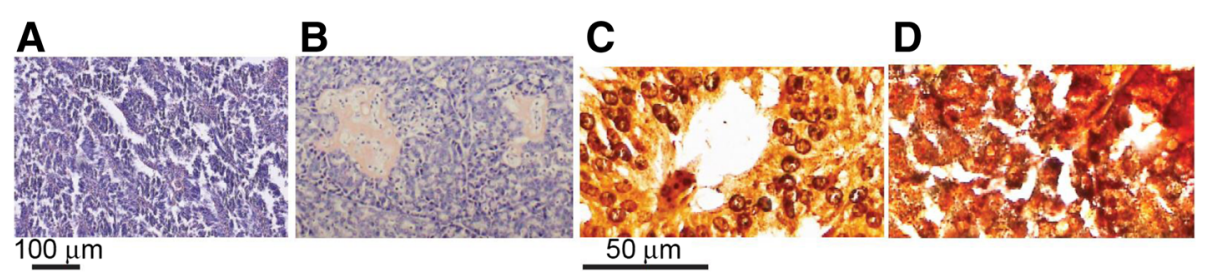

Figure 4 Congo red and Grimelius staining of the islet cells from an Atlantic wolffish. Congo red: (A) Atlantic wolffish. (B) Positive control from a feline pancreatic tissue with islet amyloidosis. Grimelius: (C) Atlantic wolffish. (D) Positive control from a canine adrenal tumor.

found in the IAPP amino acid sequences of the Atlantic wolffish and the zebrafish, but not in Atlantic salmon or daddy sculpin.

We compared the in silico potential of IAPP to form $\beta$-sheet precipitates, as expressed by the Agg parameter (Table 1). The human IAPP amyloidogenic sequence has the highest Agg parameter. Among the mammals, the rat non-amyloidogenic IAPP sequence shows the lowest Agg parameter. Interestingly, the Atlantic wolfish and the zebrafish exhibit a null Agg parameter, and the daddy sculpin Agg parameter is lower than the rat. In contrast, the Atlantic salmon IAPP sequence reveals Agg parameter higher than the cat, though spontaneous islet amyloidosis has not yet been reported.

\section{Discussion}

The pancreatic islets in the Atlantic wolffish appear as a few grossly evident nodules embedded in pancreatic parenchyma, designated Brockmann bodies in other teleost species. These are the homologs of the islets of Langerhans as has been previously described in other teleostean fish (Falkmer 1961). According to the Grimelius staining, the pancreatic tissues did not contain neuroendocrine cells, which preclude the islet nodule as the occurrence of a neuroendocrine tumor.
Demonstrated via immunofluorescence, the $\alpha$ cells (glucagon) occur at the periphery of the islet, and the $\beta$ cells are distributed throughout the entire nodule. This distribution of islet cells is similar for other teleost species such as the daddy sculpin (M. scorpius) (Falkmer and Olsson 1962; Stefan and Falkmer 1980), gilthead sea bream (Sparus auratus L.) (Abad et al. 1986), swordtail (Xiphophorus helleri H.) (Klein and Lang 1977), and rosy barb (Barbus conchonius) (Rombout and Taverne-Thiele 1982).

Antibodies against somatostatin, pancreatic polypeptide, or synaptophysin did not react with nodular islet tissue, perhaps because the specific epitope does not occur in the Atlantic wolffish. Further research will be necessary to evaluate specific antibodies against teleostean proteins or clarify the affinity of current antibodies to each protein in teleostean fish. However, $\delta$ cells, which secrete somatostatin, are reported to be located near the $\beta$ cells (Stefan and Falkmer 1980; Abad et al. 1986; Klein and Van 1978), and pancreatic polypeptide is found in the Brockmann bodies near the pylorus in other teleostean fish (Stefan and Falkmer 1980; Rombout and Taverne-Thiele 1982).

Chromogranin A was found in the exocrine pancreas and lining the connective tissue capsule of the pancreatic islet as previously reported with other teleostean fish (Falkmer and Olsson 1962; Stefan and Falkmer 1980; Abad et al. 1986; Klein and Lang 1977; Rombout

Table 1 Identification of the 37 amino acids of IAPP using PCR and sequencing

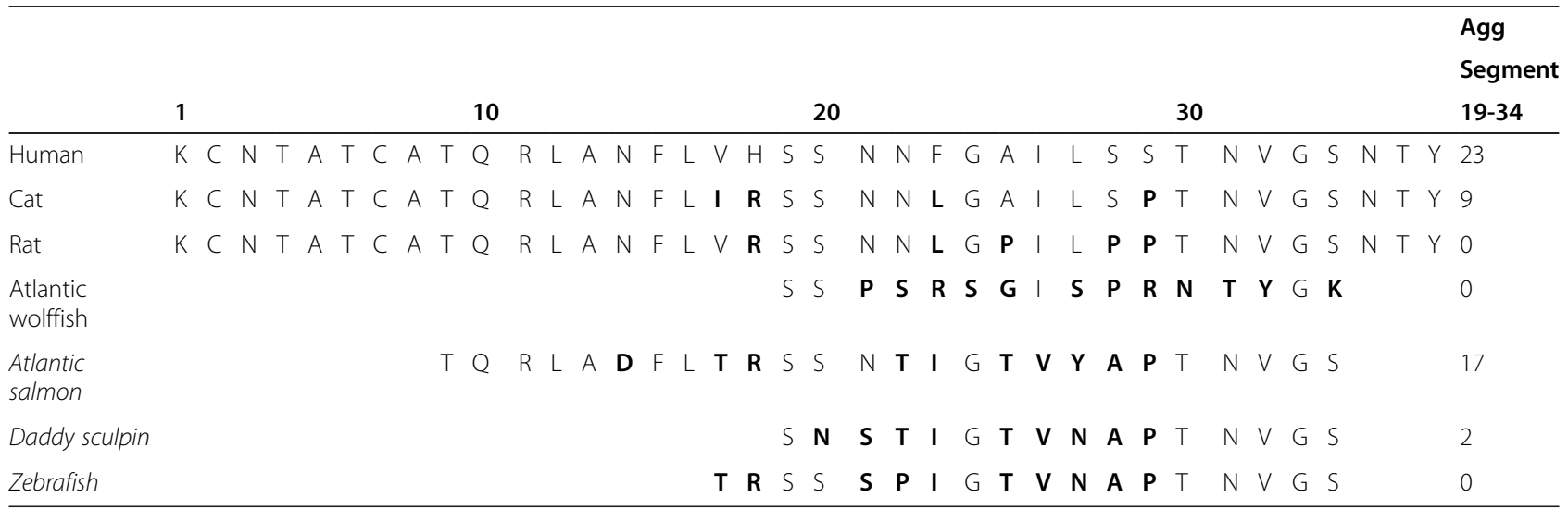

The amino acid sequences of teleost fish are compared to the amyloidogenic (human, cat) or non-amyloidogenic (rat) sequences. Sequences from species written in italics were obtained from a published work (Westermark et al. 2002). The Agg parameters were obtained using the Tango algorithm. The amino acids in boldface represent amino acid variations between species. 
and Taverne-Thiele 1982). Nodules or discrete areas consisting of a dense and compact mass of acinar cells were observed and was chromogranin immunofluorescent, confirming an exocrine origin.

IAPP or amylin (the precursor to amyloid) was identified at the peripheral region of the islets for the Atlantic wolffish, co-localizing with glucagon. In contrast to these results in the Atlantic wolffish, IAPP has been localized in endocrine pancreas of mammals, co-localizing with insulin within the $\beta$ cells and centrally, but not peripherally in the islets of the Atlantic salmon (S. salar) (Westermark et al. 2002). Amyloid was not found in the pancreatic tissues from the ten Atlantic wolffish.

IAPP has been previously isolated and characterized in three species of teleosts: zebrafish (D. rerio), Atlantic salmon ( $S$. salar), and daddy sculpin (M. scorpius) (Westermark et al. 2002; Martinez-Alvarez et al. 2008). The amino acid sequences are different for the daddy sculpin, Atlantic salmon, zebrafish, and Atlantic wolffish (Table 1). Compared to mammals, the teleosts herein do not present the GAILS region (segment 24-28), which contributes to the amyloid formation in human and cats. The Atlantic salmon IAPP was shown to be amyloidogenic in vitro (Westermark et al. 2002). Interestingly, the Atlantic salmon Agg parameter was higher than the cat IAPP segment 19-34, which is known to be amyloidogenic in vivo. The in silico analysis performed with the Tango algorithm revealed that the Anarhichas IAPP segment 19-34 was not prone to form amyloid fibrils. The Atlantic wolffish and the zebrafish have two proline residues in contrast to the other teleost fish which have only one residue. Proline residues are known to protect against fibril formation (Westermark et al. 2011); thus, their presence possibly explains the lowest Agg parameter obtained from the Tango algorithm in the Atlantic wolfish and the zebrafish. However, further research is needed to evaluate the potential of fish full-length IAPP to form amyloid deposits.

\section{Conclusions}

We confirmed the species-specific differences in the hormonal tissue distribution in teleost fish and demonstrated a unique distribution of IAPP in the Atlantic wolffish. The presence of this difference in the population of cells secreting IAPP deserves further investigation. Previous phylogenetic analyses have shown that pancreatic peptides are relatively well conserved among vertebrates. However, the IAPP amino acid sequence differs among teleost fish. Our study shows that the Atlantic wolffish is devoid of amyloid in vivo and the segment 19-34 is non-amyloidogenic, according to the in silico secondary structure analysis. Amyloidosis of pancreatic islets would not be expected as a spontaneous disease in the Atlantic wolffish. The Atlantic wolffish thus could be a potential candidate to isolate the endocrine tissues for pancreatic xenografts. This study adds new insight in the characterization of fish pancreatic peptides whose physiological functions remain to be elucidated.

\section{Competing interests}

The authors declare that they have no competing interests.

\section{Authors' contributions}

JSF performed the experimental work and data analysis and drafted the manuscript. ASB, AD, and SL collected pancreatic tissues. All authors read and approved the final version of the manuscript.

\section{Acknowledgements}

The authors acknowledge the financial support of the Diabète Québec foundation. Jessica S. Fortin was also a recipient of a studentship from IRSC. We would like to thank Dr. Wong's collaboration (Biodome) for this study and also Dr. Carl Gagnon and Dr. Josée Harel for the access to their apparatus.

\section{Author details}

${ }^{1}$ Département de pathologie et de microbiologie, Faculté de médecine vétérinaire, Université de Montréal, 3200 Sicotte, Saint-Hyacinthe, QC J2S 2M2, Canada. ${ }^{2}$ Département des sciences cliniques, Faculté de médecine vétérinaire, Université de Montréal, 3200 Sicotte, Saint-Hyacinthe, QC J2S 2M2, Canada.

Received: 26 June 2014 Accepted: 23 December 2014

Published online: 21 January 2015

\section{References}

Abad ME, Agulleiro B, Rombout JH (1986) An immunocytochemical and ultrastructural study of the endocrine pancreas of Sparus auratus $L$. (Teleostei). Gen Comp Endocrinol 64:1-12

Ali S (1985) Microvasculature of the principal islets in the scorpion fish, Myoxocephalus scorpius. Arch Histol Jpn 48:363-371

Conlon JM, Schmidt WE, Gallwitz B, Falkmer S, Thim L (1986) Characterization of an amidated form of pancreatic polypeptide from the daddy sculpin (Cottus scorpius). Regul Pept 16:261-268

Conlon JM, Davis MS, Falkmer S, Thim L (1987a) Structural characterization of peptides derived from prosomatostatins I and II isolated from the pancreatic islets of two species of teleostean fish: the daddy sculpin and the flounder. Eur J Biochem 168:647-652

Conlon JM, Falkmer S, Thim L (1987b) Primary structures of three fragments of proglucagon from the pancreatic islets of the daddy sculpin (Cottus scorpius). Eur J Biochem 164:117-122

Cutfield SM, Cutfield JF (1993) A second glucagon in the pancreatic islets of the daddy sculpin Cottus scorpius. Gen Comp Endocrinol 91:281-286

Cutfield JF, Cutfield SM, Carne A, Emdin SO, Falkmer S (1986) The isolation, purification and amino-acid sequence of insulin from the teleost fish Cottus scorpius (daddy sculpin). Eur J Biochem 158:117-123

Cutfield SM, Carne A, Cutfield JF (1987) The amino-acid sequences of sculpin islet somatostatin-28 and peptide YY. FEBS Lett 214:57-61

Falkmer S (1961) Experimental diabetes research in fish. Acta Endocrinol (Copenh) Supplementum 37(Suppl 59):1-122

Falkmer S, Olsson R (1962) Ultrastructure of the pancreatic islet tissue of normal and alloxan-treated Cottus scorpius. Acta Endocrinol (Copenh) 39:32-46

Intine RV, Olsen AS, Sarras MP Jr (2013) A zebrafish model of diabetes mellitus and metabolic memory. J Vis Exp 72:e50232

Klein C, Lang RH (1977) Principal cell types in the pancreatic islet of a teleost fish, Xiphorphorus helleri $\mathrm{H}$. Cell Tissue Res 176:529-551

Klein C, Van NS (1978) Use of immunocytochemical staining of somatostatin for correlative light and electron microscopic investigation of D cells in the pancreatic islet of Xiphophorus helleri H. (Teleostei). Cell Tissue Res 194:399-404

Liu C, Koeberlein B, Feldman MD, Mueller R, Wang Z, Li Y, Lane K, Hoyt CC, Tomaszewski JE, Naji A, Rickels MR (2012) Accumulation of intrahepatic islet amyloid in a nonhuman primate transplant model. Endocrinology 153:1673-1683

Martinez-Alvarez RM, Volkoff H, Cueto JA, Delgado MJ (2008) Molecular characterization of calcitonin gene-related peptide (CGRP) related peptides 
(CGRP, amylin, adrenomedullin and adrenomedullin-2/intermedin) in goldfish (Carassius auratus): cloning and distribution. Peptides 29:1534-1543

McGonnell IM, Fowkes RC (2006) Fishing for gene function—endocrine modelling in the zebrafish. J Endocrinol 189:425-439

Nguyen TM, Wright JR Jr, Nielsen PF, Conlon JM (1995) Characterization of the pancreatic hormones from the Brockmann body of the tilapia: implications for islet xenograft studies. Comp Biochem Physiol C Pharmacol Toxicol Endocrinol 111:33-44

Rombout JH, Taverne-Thiele JJ (1982) An immunocytochemical and electronmicroscopical study of endocrine cells in the gut and pancreas of a stomachless teleost fish, Barbus conchonius (Cyprinidae). Cell Tissue Res 227:577-593

Stefan Y, Falkmer S (1980) Identification of four endocrine cell types in the pancreas of Cottus scorpius (Teleostei) by immunofluorescence and electron microscopy. Gen Comp Endocrinol 42:171-178

Westermark GT, Falkmer S, Steiner DF, Chan SJ, Engstrom U, Westermark P (2002) Islet amyloid polypeptide is expressed in the pancreatic islet parenchyma of the teleostean fish, Myoxocephalus (cottus) scorpius. Comp Biochem Physiol B Biochem Mol Biol 133:119-125

Westermark P, Andersson A, Westermark GT (2011) Islet amyloid polypeptide, islet amyloid, and diabetes mellitus. Physiol Rev 91:795-826

Wright JR Jr, Pohajdak B, Xu BY, Leventhal JR (2004) Piscine islet xenotransplantation. ILARJ 45:314-323

Yang H, Dickson BC, O'Hali W, Kearns H, Wright JR Jr (1997) Functional comparison of mouse, rat, and fish islet grafts transplanted into diabetic nude mice. Gen Comp Endocrinol 106:384-388

\section{Submit your manuscript to a SpringerOpen ${ }^{\circ}$ journal and benefit from:}

- Convenient online submission

- Rigorous peer review

- Immediate publication on acceptance

- Open access: articles freely available online

- High visibility within the field

- Retaining the copyright to your article 